\title{
Cardiac Schwannoma
}

National Cancer Institute

\section{Source}

National Cancer Institute. Cardiac Schwannoma. NCI Thesaurus. Code C5358.

A benign peripheral nervous system neoplasm that is composed of well-differentiated Schwann cells and affects the heart. 